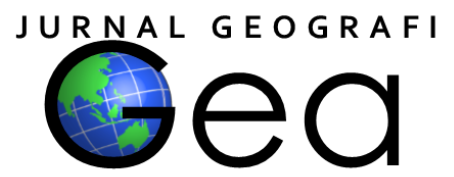

\title{
SINTESA GEOMORFOLOGI ANTROPOSEN KAWASAN CAGAR ALAM GEOLOGI KARANGSAMBUNG BAGIAN SELATAN
}

\author{
Puguh Dwi Raharjo $^{1 *}$, Eko Haryono ${ }^{2}$ \\ ${ }^{1}$ Pusat Penelitian Geoteknologi, LIPI \\ ${ }^{2}$ Departemen Geografi Lingkungan, Fakultas Geografi, UGM \\ *puguh.draharjo@karangsambung.lipi.go.id
}

\begin{abstract}
The earth's surface is experiencing dynamic developments, not only in changes in land use types but also in detailed geomorphological landforms. This dynamic change is caused by the human need for land. Java Island has a diverse physiography, this is due to volcanic activity and uplifting as well as erosion and sedimentation. Karangsambung area is an area with hilly topography and exposed many rocks which are evidence of tectonic processes. A lot of rock outcrops and in a relatively large area, resulted in agriculture not being dominant. The community tends to take advantage of the location as a place for mining. Mining carried out by the community in the Karangsambung area including rocks that have commercial functions. In addition, high erosion and sedimentation training in sand mining in the deposition area. Mining is carried out widely and gradually causes environmental problems. This study aims to see the impact of human activities on natural conditions in the southern part of Karangsambung Nature Reserve. The spatial approach uses remote sensing image data as an early indication. The results obtained are that in the Karangsambung area there are 3 human activities that cause changes in land shape, namely changes from alluvial plains to floodplains and fluvial plains. Changes in sinuosity due to sedimentation and landslides damage due to slope cutting, as well as changes from hills of diabas intrusion to degraded land with flat topography. These changes have a bad impact on the environment, resulting in handling from various sector.
\end{abstract}

Keywords: anthropocene, geomorphology, karangsambung, lukulo, sedimentation

\begin{abstract}
ABSTRAK
Permukaan bumi mengalami perkembangan secara dinamis, tidak hanya pada perubahan jenis penggunaan lahan namun juga pada bentuklahan geomorfologi secara detail. Perubahan dinamis ini disebabkan adanya kebutuhan manusia mengenai lahan. Pulau Jawa memiliki fisiografi yang beragam, hal ini dipengaruhi oleh aktivitas vulkanik dan pengangkatan wilayah serta erosi dan sedimentasi. Kawasan Karangsambung merupakan daerah dengan topografi perbukitan dan tersingkap banyak batuan yang merupakan bukti dari proses tektonik. Singkapan batuan yang banyak dan pada daerah yang realitif luas, mengakibatkan pertanian tidak dominan. Masyarakat cenderung memanfaatkan keberadaan lokasi sebagai tempat untuk penambangan. Penambangan yang dilakukan oleh masyraakat di Kawasan Karangsambung meliputi batuan-batuan yang dianggap memiliki fungsi komersil. Selain itu erosi dan sedimentasi yang tinggi memicu penambanggan pasir pada daerah pengendapan. Penambangan yang dilakukan dilakukan secara luas dan berangsur-angsur menyebabkan permasalahan lingkungan. Pada penelitian ini bertujuan mengetahui dampak dari aktivitas manusia terhadap kondisi alamiah di Kawasan Cagar Alam Karangsambung bagian selatan.
\end{abstract}


Pendekatan keruangan menggunakan data citra penginderaan jauh sebagai identifikasi awal. Hasil yang diperoleh bahwa pada Kawasan Karangsambung terdapat 3 aktivitas manusia yang menyebabkan perubahan bentuklahan, yaitu perubahan dari dataran aluvial menjadi dataran banjir dan ledok fluvial, perubahan sinuositas sungai akibat sedimentasi dan longsoran akibat pemotongan lereng, serta perubahan dari perbukitan intrusi diabas menjadi lahan rusak topografi datar. Perubahan-perubahan ini mengakibatkan dampak buruk bagi lingkungan, sehingga diperlukan penanganan dari berbagai pihak.

Kata kunci: antroposen, geomorfologi, karangsambung, lukulo, sedimentasi

\section{PENDAHULUAN}

Konsep antroposen memberikan kerangka konseptual mengenai kondisi global saat ini di mana masyarakat memiliki pengaruh dominan yang semakin besar pada fungsi sistem bumi (Meybeck, 2003; Steffen et al., 2011; Verburg et al., 2016). Permukaan bumi mengalami perkembangan secara dinamis, tidak hanya pada perubahan jenis penggunaan lahan namun juga pada bentuklahan geomorfologi secara detail (Zalasiewicz et al., 2011; Waters et al., 2016; Goudie, 2018). Perubahan dinamis ini disebabkan adanya kebutuhan manusia mengenai lahan. Anthropocene mewakili fase baru dalam sejarah umat manusia dan Bumi, ketika kekuatan alam dan kekuatan manusia menjadi saling terkait (Zalasiewicz et al., 2011). Manusia telah memodifikasi bentang alam dan proses yang membentuknya selama Anthropocene (Goudie and Viles, 2016), aktivitas manusia tersebut telah memodifikasi lebih dari setengah luas daratan (Jefferson, Wegmann and Chin, 2013).

Geomorfologi antroposen tidak dimulai dari revolusi industri, namun sudah ada sejak pada jaman pertanian, ketika pertanian sudah merubah bentang lahan permukaan (Zalasiewicz et al., 2010). Antroposen awal sudah ada sejak kehidupan Suku Maya yang (3000 hingga $1000 \mathrm{BP}$ ) yang merubah lahan hutan yang komplek menjadi perkotaan, dengan bukti vegetasi, hidrologi dan litosfer, dari studi tanah, danau, dataran banjir, lahan basah, dan ekosistem lainnya (Beach et al., 2015). Dampak aktivitas manusia pada sistem global relatif terhadap fungsi alami (Downs and Piegay, 2019).Peningkatan kepentingan manusia telah menjadi agen perubahan geomorfologi (Goudie, 2018).

Konsep geomorfologi (Thornbury W.D, 1954) yang berkaitan erat dengan evolusi dan perubahan bentuklahan akibat manusia adalah konsep yang ke-5 yang menyatakan bahwa media erosi yang berbeda pada permukaan bumi membentuk susunan bentuklahan tertentu. Morfologi hanya mencerminkan proses erosi/pengendapan dan tergantung pada kondisi iklim dan topografi (Pellegrini and Vercesi, 2017). Penelitian geomorfologi telah lama mengakui dampak aktivitas manusia pada lanskap fluvial (Downs and Piegay, 2019). Interaksi antara morfologi dan sedimentasi yang menyebabkan distribusi sungai semakin sempit, dan dangkal, debit semakin berkurang berdampak pada hilangnya penahanan di bagian hilir dan membentuk endapan baru (Skalak et al., 2013; Assine et al., 2015), hal ini merupakan bentuk dari restorasi daerah hulu (Wohl, 2018).

Pulau Jawa memiliki fisiografi yang beragam, hal ini dipengaruhi oleh aktivitas vulkanik dan pengangkatan wilayah serta erosi dan sedimentasi (Bemmelen, 1949). Kawasan Karangsambung merupakan daerah dengan topografi perbukitan dan tersingkap banyak batuan yang merupakan bukti dari proses tektonik (Asikin, 1974; Prasetyadi, 2007). Hal ini dikeranakan daerah ini merupakan zona penunjaman lempeng IndiaAustralia ke lempeng Eurasia (Hamilton, 1979; Hoffmann-Rothe, Ritter and Haak, 2001). Manusia mempengaruhi penutup lahan/deforestasi menyebabkan peningkatan erosi dan sedimentasi serta dinamika sungai (Goudie, 2018; Wohl, 2018). Peningkatan adopsi konsep Anthropocene akan merusak tujuan konservasi dan restorasi (Caro et al., 2012).

Singkapan batuan yang banyak dan pada daerah yang realitif luas, mengakibatkan pertanian tidak dominan. Masyarakat cenderung memanfaatkan keberadaan lokasi 
sebagai tempat untuk penambangan. Penambangan yang dilakukan oleh masyarakat di Kawasan Karangsambung meliputi batuan-batuan yang dianggap memiliki fungsi komersil. Selain itu erosi dan sedimentasi yang tinggi memicu penambanggan pasir pada daerah pengendapan. Penambangan yang dilakukan dilakukan secara luas dan berangsur-angsur menyebabkan permasalahan lingkungan. Pada penelitian ini bertujuan mengetahui dampak dari aktivitas manusia terhadap kondisi alamiah di Kawasan Cagar Alam Karangsambung bagian selatan.

\section{METODE PENELITIAN}

Penelitian ini berlokasi di Cagar Alam Geologi Karangsambung bagian selatan yang secara administrasi berada di Kecamatan Karangsambung Kabupaten Kebumen (Gambar 1). Data citra multi-temporal (Citra Landsat Tahun 1989 dan Tahun 2018) digunakan sebagai bahan data untuk mengetahui perubahan fisik permukaan. Pendekatan keruangan berdasarkan resolusi spasial merupakan analisis awal untuk mengetahui gejala perubahan awal bentuklahan dari waktu ke waktu. Spasial variabilitas dalam proses geomorfik mengatur pola gangguan secara temporal yang mempengaruhi struktur dan dinamika ekosistem (Montgomery, 1999).

Karakteristik obyek menjadikan penelitian ini memiiliki sebuah metode survei. Penyelidikan perubahan bentuklahan ini dilakukan untuk mengetahui proses dan genesa serta hubungannya dengan aktivitas manusia dalam skala insitu. Gejala-gejala yang diamati dilapangan merupakan gejala alamiah dan sosial (aktivitas manusia terhadap alam) serta mempertimbangkan historis dan kronologis lokasi penelitian. Kronologis yang dimaksud pada penelitain ini adalah kronologis perubahan bentuklahan akibat pengaruh aktivitas manusia.

Tinjauan sistematis dilakukan terhadap studi yang berfokus pada dampak kumulatif dari aktivitas manusia berupa perubahan dan respon geomorfologi bentuklahan (Downs and Piegay, 2019), yaitu meliputi:

a) Melibatkan perspektif historis, bukan hanya berdasarkan jangkauan;

b) Mengintegrasikan dampak dari serangkaian kegiatan yang komprehensif untuk perubahan bentuklahan

c) Perubahan yang dibedakan pada skala insitu, bukan hanya menunjukkan tren umum;

d) Fokus pada sebab dan akibat, bukan hanya menggambarkan perubahan.

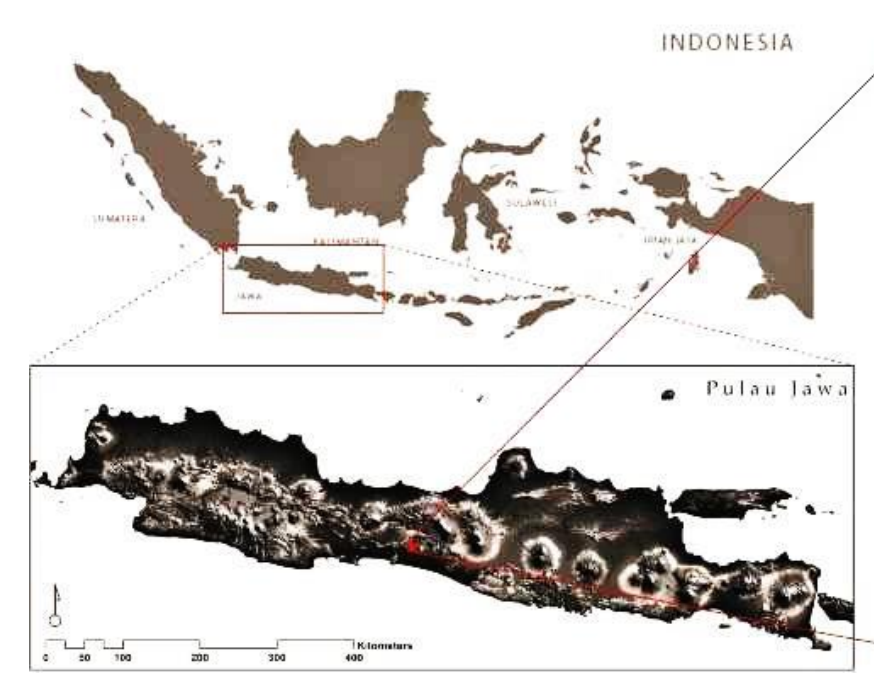

Gambar 1. Lokasi penelitian di Kawasan Cagar Alam Geologi Karangsambung bagian selatan

Teknik pengumpulan data pada penelitian dilakukan dengan teknik menggunakan data penginderaan jauh dan dengan menggunakan observasi. Pengumpulan data menggunakan data penginderaan jauh dimaksudkan untuk identifikasi obyek dan persebaran bentuklahan yang mengalami perubahan di Kawasan Cagar Alam Geologi Karangsambung. Observasi yang dilakukan guna memperoleh data-data secara detail mengenai sebab akibat peribahan bentuklahan serta aktivitas manusia yang mempengaruhinya. 


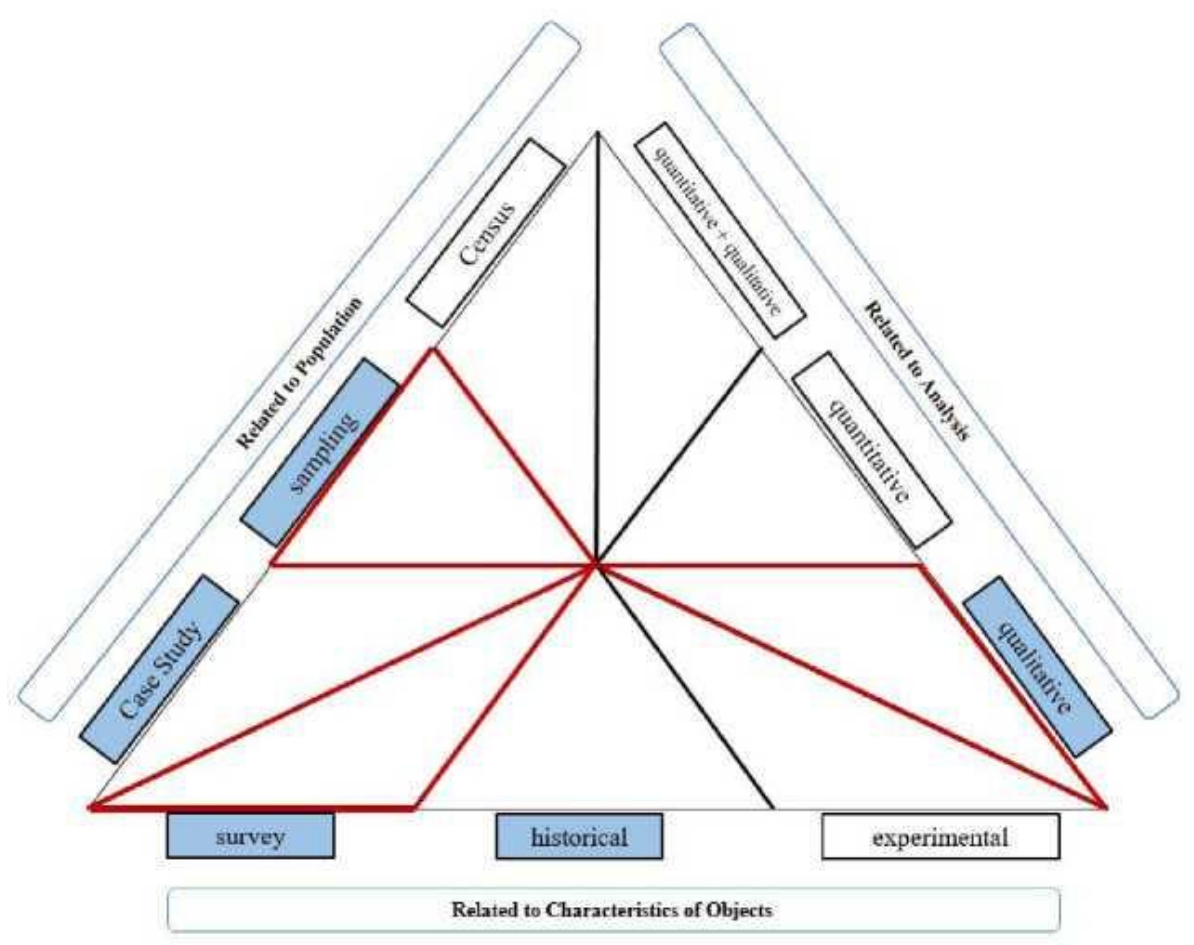

Gambar 2. Desain penelitian (Yunus, 2010, dengan perubahan)

\section{HASIL DAN PEMBAHASAN}

Kawasan Karangsambung memiliki singkapan batuan tersebar secara luas. Faktor ini memberikan dampak secara alamiah penyebab perubahan permukaan lahan yang dipicu oleh aktivitas manusia. Kebutuhan dan aktivitas manusia akan permukaan lahan mengakibatkan perubahan konfigurasi permukaan bumi. Perubahan permukaan bentuklahan secara detail akibat adanya campur tangan manusia pada Kawasan Karangsambung terlihat pada bentuklahan fluvial dan bentuklahan denusional. Kedua proses ini semua berdampak pada perubahan morfologi Sungai Lukulo.

Sungai Lukulu Hulu memiliki nilai morfometri yang menunjukan tingkat pengaliran permukaan tinggi dan waktu konsentrasi cepat (Raharjo et al., 2016), hal tersebut memberikan dampak erosi yang tinggi pada Sungai Lukulo Hulu. Erosi pada DAS Lukulo Hulu memiliki kriteria erosi berat dan sangat berat sekitar 2963,75 ton/ha/tahun (Raharjo and Saifudin, 2008), sedangkan muatan sedimen yang terendapkan di outlet Sungai Lukulo Hulu sekitar 194,43 ton/ha/tahun (Saifudin and Raharjo, 2009).

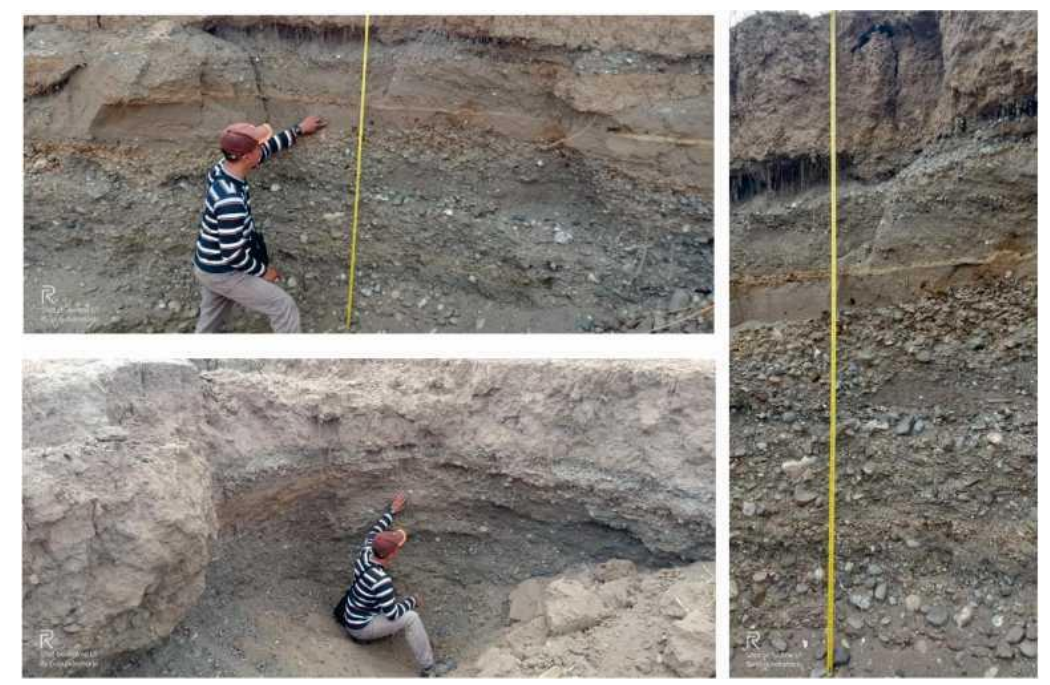

Gambar 3. Lapisan pada dataran aluvial Sungai Lukulo yang menandakan pernah adanya beberapa kejadian banjir (Foto: Puguh D. Raharjo, 2019) 

Topografi Kawasan Karangsambung sebagian besar merupakan daerah perbukitan dan dataran sebagai tempat akumulasi aliran hanya memiliki luasan yang kecil (Raharjo, 2010; Raharjo et al., 2017). Sedimentasi berupa endapan pasir banyak ditemukan disepanjang Sungai Lukulo. Endapan sedimen pasir berada pada hamparan luas dan proses ini berlangsung dalam periode waktu yang relatif lama. Dataran aluvial yang luas di Desa Karangsambung dan Desa Banioro Kecamatan Karangsambung merupakan daerah yang pernah mengalami kondisi banjir pada masa lampau. Hal ini terlihat dari adanya lapisan endapan sedimentasi dengan perulangan pola sortasi (Gambar 3). Lapisan menunjukkan dari bawah hingga atas berupa kerikil besar, kerikil kecil, pasir kasar, pasir halus, tanah, dan mengalami perulangan hingga 3 kali dengan urutan lapisan yang sama.

Dataran aluvial (Gambar 4) merupakan akumulasi aliran yang membawa sediemen dan terendapkan. Potensi pasir yang banyak ini menjadikan manusia memanfaatkan sebagai lokasi penambangan pasir. Penambangan pasir ini dilakukan secara berlebihan dan hingga pada lokasi yang tidak terpengaruh oleh sungai pada saat ini. Penambangan yang terjadi tidak hanya berdampak secara tidak langsung terhadap perubahan bentuklahan, namun juga mengakibatkan perubahan secara langsung terhadap morfologi bentuklahan asal proses fluvial. Penambangan pasir pada Sungai Lukulo ini merupakan pengaruh pertama dari aktivitas manusia yang mempengaruhi bentukan geomorfologi yang ada di Kawasan Cagar Alam Geologi Karangsambung.

Perubahan morfologi bentukan lahan asal proses fluvial yang terjadi secara langsung adalah berubahnya bentuk lahan dataran banjir dan dataran aluvial menjadi ledok fluvial (Gambar 4.A). Pada awal penambangan pasir di Kawasan Karangsambung hanya dilakukan di sekitara daerah- daerah sedimentasi pada poin barpoin bar pada sungai yang memiliki sinuositas tinggi. Kebutuhan dan permintaan pasir sebagai bahan bangunan yang cukup tinggi, penambangan dilakukan pada lokasi yang memiliki endapan pasir namun pada saat sekarang sudah tidak terkena proses sedimentasi. Penambangan yang dilakukan pada awalnya masih berupa manual, sekarang sudah menggunakan alat berat dan mesinmesin penyedot pasir. Hal ini yang dimungkinkan mempercepat proses perubahan roman muka bumi di Karangsambung.

Perubahan bentuklahan ini merubah fungsi dan karakteristik permukaan. Lokasi tersebut pada saat masih berupa dataran aluvial memiliki fungsi sebagai lahan pertanian produktif. Lahan padi dan tembakau merupakan tanaman pertanian yang ada pada daerah tersebut. Produksi bulanan merupakan hasil yang masyarakat peroleh dengan nilai penghasilan yang beragam. Keinginan penghasilan secara instan mulai merubah pola piker yang ada di masyarakat. Pertambangan pasir memberikan hasil yang secara instan, secara langsung. Masyarakat menyewakan lahan pertanian kepada penambang dengan perhitungan volume dan jumlah hari. Model penyewaan lahan sebagai penambangan menjadi trend di kalangan masyarakat.

Masyarakat tidak mempertimbangkan dampak yang akan diperoleh di masa datang. Bencana banjir dan kelangkaan sumber daya air tanah menjadi permasalahan baru. Banjir pada lokasi ini merupakan banjir yang terjadi secara periodik. Dataran aluvial yang ada di Kawasan Karangsambung merupakan lokasi yang sangat penting di masyarakat. Sumursumur yang dibuat oleh masyarakat rata-rata berada di dataran aluvial. Tipe sungai merupakan influent, air sungai memenuhi pasokan pada sumur-sumur warga yang ada di dataran aluvial. Penambangan pasir juga dilakukan pada tubuh air pada sungai, dan dilakukan dengan menggunakan mesin sedot. Hal ini berakibat pada turunnya muka air tanah sumur masyarakat yang berada di sekitar dataran aluvial (Widiyanto et al., 2013).

Pengaruh dari penambangan ini juga menimbulkan dampak lain, seperti halnya perubahan pada morfologi sungai. Perubahan yang yang terjadi salah satunya adalah menurunnya sinuositas sungai pada lokasi tertentu. Penurunan sinuositas lebih cenderung karena adanya perubahan arus dan sedimen sungai yang terendapkan. Pada 
penelitian ini terlihat dari identifikasi dari citra landsat Tahun 1989 dan citra landsat Tahun 2019 (Gambar 6). Penambangan pasir pada lokasi sekitar sungai tidak selamanya merugikan apabila dilakukan pada zona sedimentasi dan tidak dilakukan secara berlebihan dan harus terukur. Hal ini sedimentasi yang berlebih juga akan mengakibatkan pendangkalan sungai sehingga daya tamping air semakin berkurang. Konsep sistem aliran sungai pada dasarnya merupakan suatu keseimbangan yang dinamis yang menggambarkan penyesuaian, dalam hubungannya dengan lebar aliran, kedalaman, kecepatan, dan beban sedimen (Leopold and Maddock, 1953; Vannote et al., 1980).

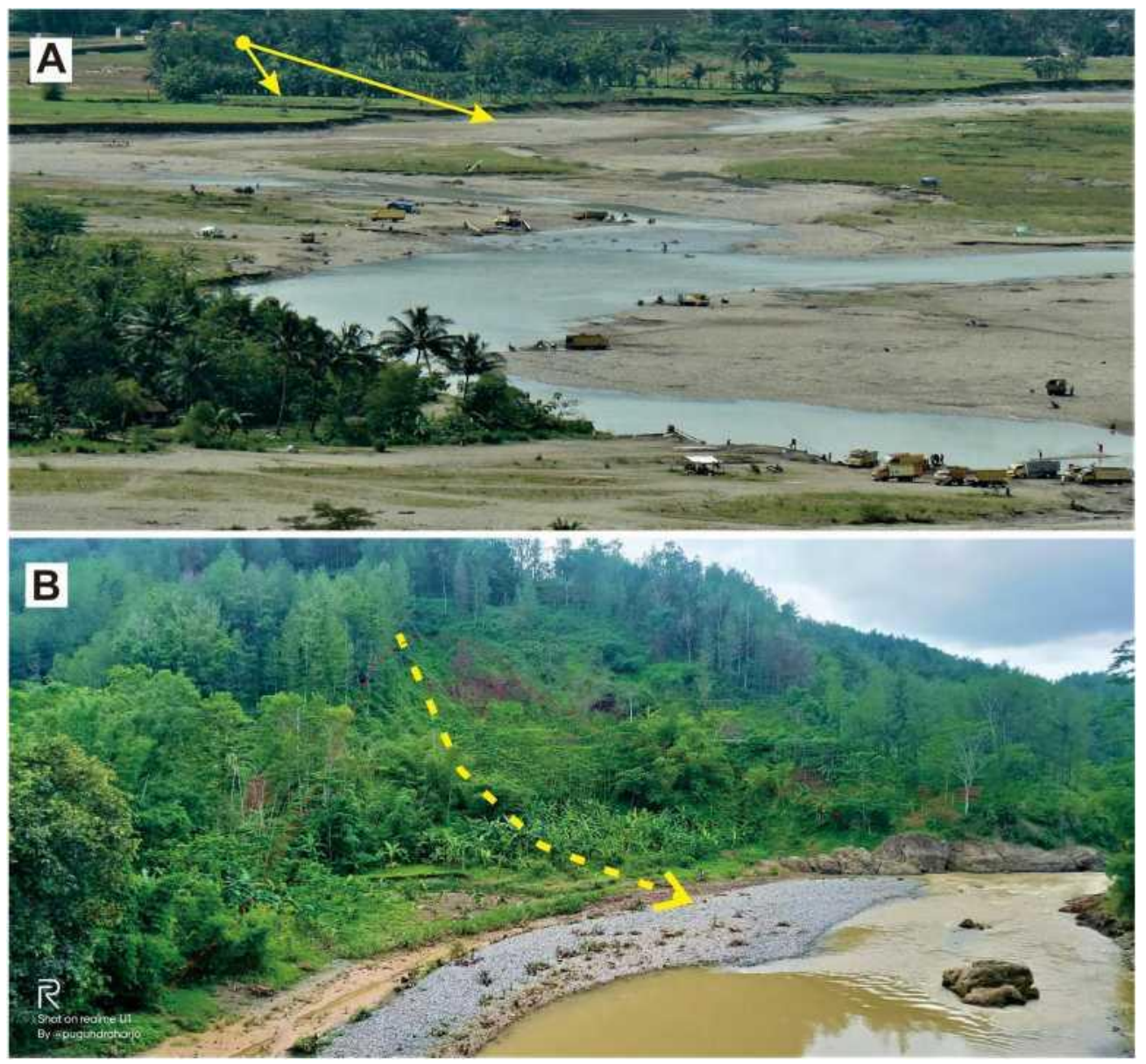

Gambar 4. Perubahan bentuklahan di sekitar sungai (A. bentuklahan dataran aluvial dan dataran banjir di Kawasan

Karangsambung yang berubah menjadi ledok fluvial akibat adanya aktivitas penambangan yang berlebih; B. perubahan sinuositas sungai akibat adanya longsoran, pemotongan lereng pada daerah perbukitan yang berada di atas sungai)

(Foto: Puguh D. Raharjo, 2019)

Penggaruh kedua dari aktivitas
manusia yang terhadap bentukan geomorfologi di Kawasan Cagar Alam Geologi Karangsambung adalah adanya pemotongan lereng pada perbukitan. Pemotongan lereng yang dilakukan untuk tujuan pelebaran jalan. Pemotongan lereng ini selain berpengaruh pada morfologi perbukitan juga memberikan dampak pada Sungai Lukulo yang berada di daerah hulu. Pemotongan lereng perbukitan yang dilakukan sekitar Sungai Lukulo dengan anak sungai (Sungai Lokidang) memberikan dampak pada perubahan morfologi Sungai Lukulo. Akibat pemotongan lereng yang terjal pada perbukitan dengan kondisi batuan yang tidak stabil (mengalami pelapukan dan tanah sebagian besar berupa regolith) mengakibatkan terjadinya longsor. Posisi tebing yang berada di atas sungai yang memiliki sinuositas tinggi. Selain berdampak pada jalan, longsoran tersebut juga mengenai tubuh sungai. Sungai pada lokasi tersebut yang semula memiliki sinuositas tinggi berubah menjadi sungai dengan sinuositas yang rendah (Gambar 4.B). 
Material longsoran yang berupa tanah dengan plastisitas yang relative tinggi tidak mampu tererosi oleh kekuatan aliran air. Sehingga aliran air yang banyak membawa endapan kasar (pasir) banyak terendapkan pada lokasi tersebut. Sinuositas luar yang semula membentuk pothole berubah menjadi lokasi dengan sedimentasi yang tinggi. Aliran sungai melakukan mekanisme dan membentuk bentukan morfologi sungai (bentuk alur) yang baru. Pada lokasi ini yang semula tidak terdapat endapan kerikil hingga pasir halus, sekarang berubah menjadi hamparan endapan yang terhimpun banyak material. Dampak lainnya akibat perubahan morfologi sungai tersebut adalah berkurannya endapan sedimen pada lokasi poin bar pada lokasi sungai dengan sinuositas yang berada dibawahnya. Evolusi saluran sungai sebagian besar mengakibatkan penyempitan, sayatan dan pengembangan teras, berkurangnya sedimen dasar, serta perubahan geometri saluran (Downs and Piegay, 2019).

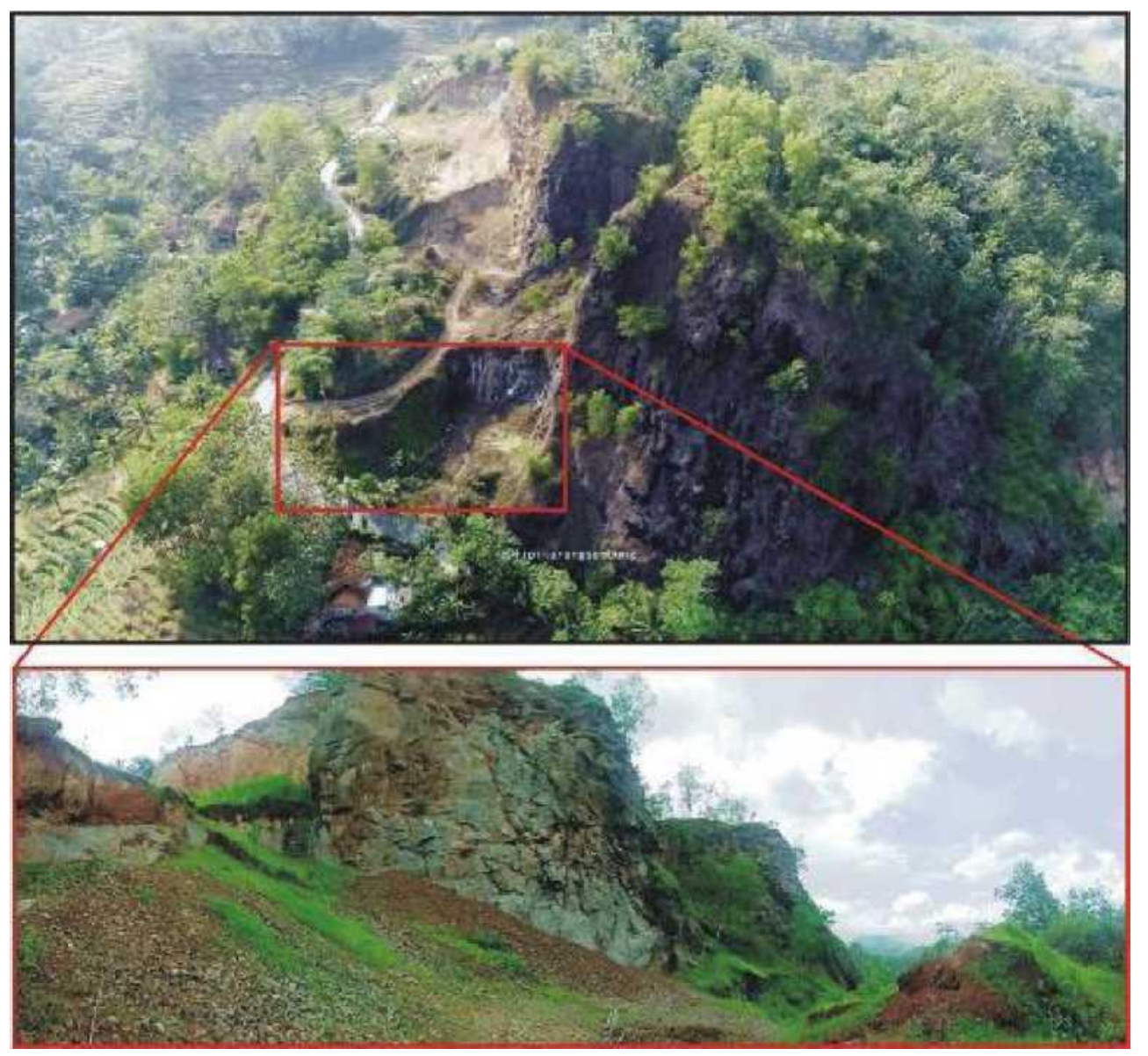

Gambar 5. Perubahan bentuklahan di tubuh intrusi, dike batuan diabas, kondisi pada saat ini menjadi bentuk lahan denudasional dengan lahan yang sudah rusak (Foto: LIPI, 2017; Puguh D. Raharjo, 2019)

Perubahan geomorfologi bentuklahan ketiga akibat pengaruh dari aktivitas manusia di Kawasan Cagar Alam Geologi Karangsambung berada di Gunung Parang Kecamatan Karangsambung. Gunung Parang ini merupakan tubuh intrusi batuan beku dalam (diabas) berupa dike. Intrusi diabas ini memiliki struktur columnar joint. Penambangan berupa batuan yang dilakukan pada lokasi ini sudah terjadi sejak lama. Perbukitan intrusi secara genetika tidak dapat dikembangkan lebih lanjut menjadi zona penambangan dikarenakan dalam nilai skenario dikembangkan bernilai negative. Sehingga bila terus dieksploitasi akan mengalami degradasi lingkungan yang sangat cepat (Widiyanto and Raharjo, 2011).

Penambangan yang dilakukan oleh masyarakat tersebut hingga mencapai setengah dari bentuklahan asal (Gambar 4.B). Kondisi sekarang lokasi sudah terlihat seperti lahan rusak dan pada bagian tertentu sudah 
tidak tampak bekas suatu bentukan topografi perbukitan. Selain perubahan bentuklahan secara ekstrem dari perbukitan menjadi lahan rusak topografi datar, pada lokasi tersebut juga memiliki kriteria ancaman longsor

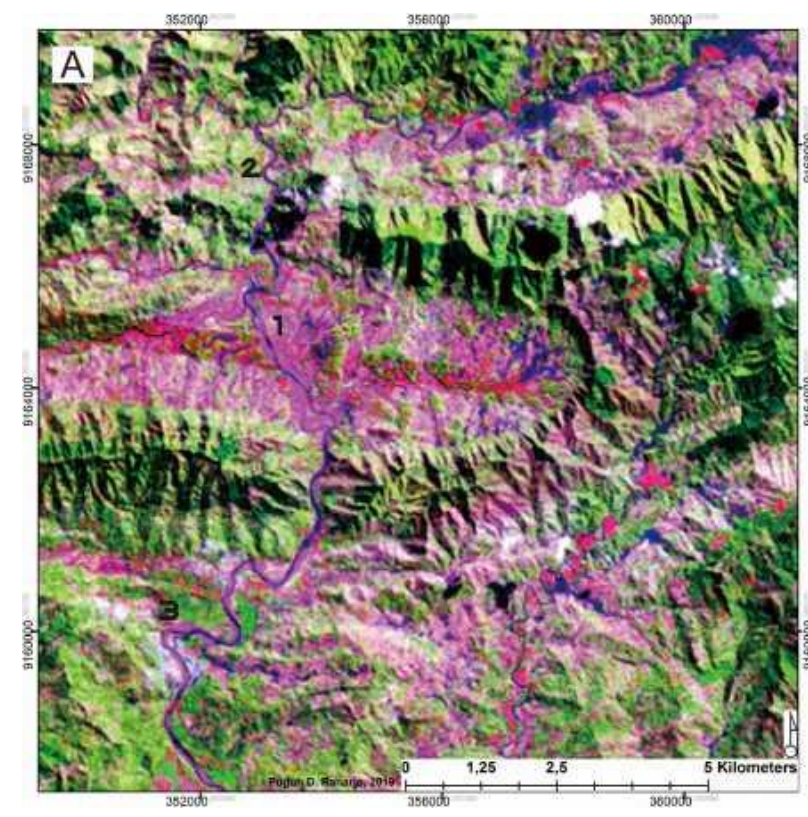

tinggi. Perbukitan intrusi dengan struktur columnar joint yang terdapat banyak retakan merupakan wilayah yang tidak stabil, sehingga adanya penambangan dapat pemicu terjadinya longsor pada lokasi ini.

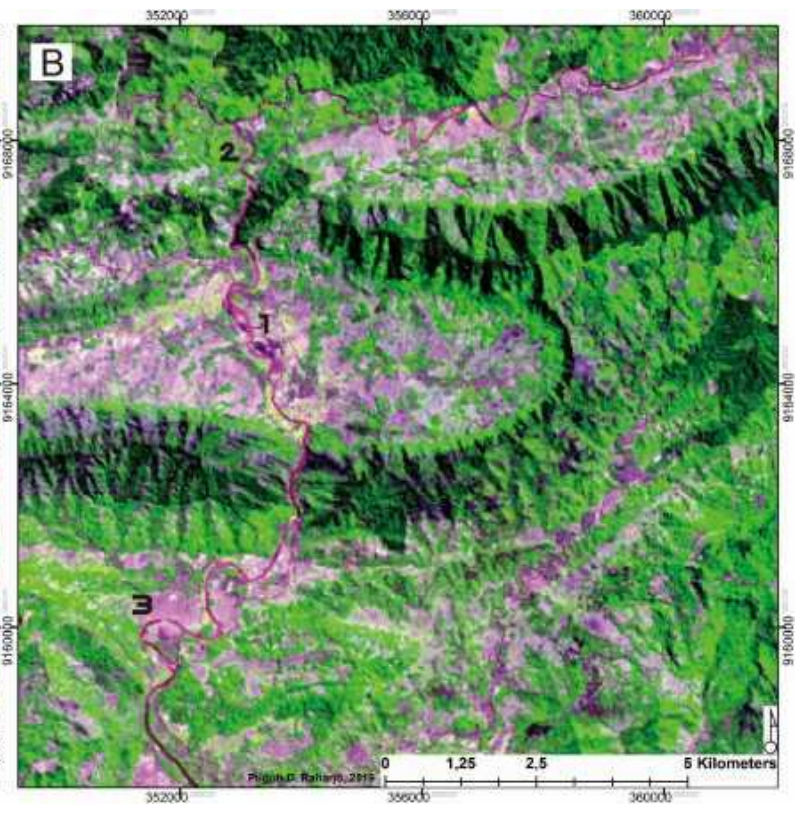

Gambar 6. Citra multispektral sebagian wilayah Cagar Alam Geologi Karangsambung, A. Landsat perekaman Tahun 1989; B. Citra Landsat perekaman Tahun 2019 (Sumber: https://earthexplorer.usgs.gov/)

Pada Gambar 6 terlihat bahwa terdapat beberapa perubahan konfigurasi permukaan, bentuklahan yang ada di Kawasan Karangsambung seperti yang telah diuraikan pada paragraf-paragraf diatas. Pada kode nomor 1 merupakan perubahan dataran aluvial pada Tahun 1989 berubah menjadi ledok fluvial dan dataran banjir pada Tahun 2018. Penambangan pada dataran aluvial (sekitar Sungai Lukulo pada lembah antiklin) yang secara langsung juga memberikan dampak pada turunnya muka air tanah.

Pada alur Sungai Lukulo kode nomor 2 terlihat adanya perubahan sinuositas, hal ini dikarenakan adanya longsoran yang menutupi sebagian sungai. Sinuositas berkurang dan aliran membentuk alur baru serta membentuk hamparan endapan baru pada lokasi yang tertutup oleh longsoran. Pada lokasi kode nonor 3 juga terjadi perubahan bentuk alur Sungai Lukulo. Hal ini dikarenakan adanya perubahan energi dari hulu yang terganggu akibat banyaknya penambangan pada tubuh sungai. Konsep penanganan yang tepat dalam mengatur penambangan sangat diperlukan oleh pemerintah, agar tidak memiliki konsekuensi parah. Selain itu juga diperlukan sosialisasi kepada para penambangan tentang etika mendasar yang dapat merusak lingkungan dan untuk melindunginya, dan untuk mengingatkan masyarakat tentang pentingnya ekosistem tersebut (Steffen, Crutzen and McNeill, 2007; Caro et al., 2012).

\section{SIMPULAN}

Aktivitas manusia sebagai faktor utama yang mengubah bentuklahan secara mikro terjadi di Kawasan Cagar Alam Geologi Karangsambung. Penambangan pasir dan batuan memberikan dampak terhadap perubahan morfologi dengan waktu yang relatif cepat. Kurun waktu Tahun 1989 hingga Tahun 2018 telah banyak mengubah konfigurasi permukaan. Pada Kawasan Karangsambung terdapat 3 lokasi yang terjadi perubahan bentuklahan geomorfologi fluvial. Perubahan nilai sinuositas dan perubahan alur sungai akibat tertutupnya badan sungai akibat longsoran pada daerah hasil pemotongan lereng. Selain itu juga adanya perubahan bentuklahan dari dataran aluvial menjadi 
dataran banjir dan ledok fluvial. Perubahan lain terjadi di perbukitan intrusi batuan diabas, penambangan yang dilakukan merubah dari topografi perbukitan menjadi topografi dataran yang telah mengalami denudasional menjadi lahan rusak.

\section{DAFTAR PUSTAKA}

Asikin, S. (1974) Evolusi Geologi Jawa Tengah dan Sekitarnya Ditinjau dari Segi Teori Tektonik Dunia yang Baru. Institut Teknologi Bandung.

Assine, M. L. et al. (2015) 'The Quaternary alluvial systems tract of the Pantanal Basin', Brazilian Journal of Geology, 45(3), pp. 475-489. doi: 10.1590/23174889201520150014.

Beach, T. et al. (2015) 'Ancient Maya impacts on the Earth's surface: An Early Anthropocene analog?', Quaternary Science Reviews. Elsevier Ltd, 124, pp. 1-30.

doi:

10.1016/j.quascirev.2015.05.028.

Bemmelen, V. (1949) The Geology of Indonesia. I.A. Government Printing Office.

Caro, T. et al. (2012) 'Conservation in the Anthropocene', Conservation Biology, 26(1), pp. 185188. doi: 10.1111/j.15231739.2011.01752.x.

Downs, P. W. and Piegay, H. (2019) 'Catchment-scale cumulative impact of human activities on river channels in the late Anthropocene: implications, limitations, prospect',Geomorphology. Elsevier B.V., 338, pp. 88-104. doi: 10.1016/j.geomorph.2019.03.021.

Goudie, A. (2018) 'The human impact in geomorphology - 50 years of change', Geomorphology. Elsevier B.V., (xxxx). doi: 10.1016/j.geomorph.2018.12.002.

Goudie, A. S. and Viles, H. A. (2016) 'Introduction to the Anthropocene and Anthropogeomorphology',

Geomorphology in the Anthropocene, pp. 1-14. doi: 10.1017/cbo9781316498910.001.

Hamilton, W. (1979) 'Tectonics of the Indonesian Region NOT FUL TEXT', Geological Society of Malaysia, Bulletin, 6(July), pp. 3-10. doi: 10.1016/0003-6870(73)90259-7.
Hoffmann-Rothe, A., Ritter, O. and Haak, V. (2001) 'Magnetotelluric and geomagnetic modelling reveals zones of very high electrical conductivity in the upper crust of Central Java', Physics of the Earth and Planetary Interiors, 124(34), pp. 131-151. doi: 10.1016/S00319201(01)00196-0.

Jefferson, A. J., Wegmann, K. W. and Chin, A. (2013) 'Geomorphology of the anthropocene: Understanding the surficial legacy of past and present human activities', Anthropocene, 2, pp. 1-3. doi: 10.1016/j.ancene.2013.10.005.

Leopold, L. B. and Maddock, T. (1953) The Hydraulic Geometrv of Stream Channels and Some Physiographic Implications. Washington, D.C. doi: https://doi.org/10.3133/pp252.

Meybeck, M. (2003) 'Global analysis of river systems: From Earth system controls to Anthropocene syndromes', Philosophical Transactions of the Royal Society B: Biological Sciences, 358(1440), pp. 1935-1955. doi: 10.1098/rstb.2003.1379.

Montgomery, D. R. (1999) 'Process domains and the River Continuum', Journal of the American Water Resources Association,35(2), pp. 397-410. doi:10.1111/j.17521688.1999.tb03598.x.

Pellegrini, L. and Vercesi, P. L. (2017) 'Landscapes and Landforms Driven by Geological Structures in the Northwestern Apennines', World Geomorphological Landscapes, pp. 203-213. doi: 10.1007/978-3-31926194-2.

Prasetyadi, C. (2007) Evolusi tektonik Paleogen Jawa bagian timur. Institut Teknologi Bandung.

Raharjo, P. D. (2010) 'Penggunaan Data Penginderaan Jauh dalam Analisis Bentukan Lahan Asal Proses Fluvial di Wilayah Karangsambung', Jurnal Geografi, 7(2), pp. 146-152. doi: https://doi.org/10.15294/jg.v7i2.85.

Raharjo, P. D. et al. (2016) 'Analisa Hidrologi Permukaan dalam Hubungannya dengan Debit Banjir DAS Lukulo Hulu dengan Menggunakan Data Penginderaan Jauh', 
Jurnal Geografi, 13(2), pp. 163-178. doi: https://doi.org/10.15294/jg.v13i2.7974.

Raharjo, P. D. et al. (2017) 'Klasifikasi bentuklahan menggunakan analisis object-based image dalam penginderaan jauh', Proceeding, Seminar Nasional Kebumian Ke-10, (September), pp. 1781-1789. Available at: https://repository.ugm.ac.id/274198/.

Raharjo, P. D. and Saifudin (2008) 'Pemetaan Erosi DAS Lukulo Hulu dengan Menggunakan Data Penginderaan Jauh dan Sistem Informasi Geografi', Jurnal Ilmu Tanah dan Lingkungan, 8(2), pp. 103-113. doi: https://doi.org/10.5072/FK2/1KXZCT.

Saifudin and Raharjo, P. D. (2009) 'Potensi endapan sedimen dalam hubungannya dengan tingkat erosi di das lukulo hulu', Prosiding Pemaparan Hasil Penelitian Puslit Geoteknologi - LIPI2009, pp. 205-213. doi: https://doi.org/10.5072/FK2/OOD1PD.

Skalak, K. J. et al. (2013) 'Large dams and alluvial rivers in the Anthropocene: The impacts of the Garrison and Oahe Dams on the Upper Missouri River', Anthropocene. Elsevier B.V., 2, pp. 5164. doi: 10.1016/j.ancene.2013.10.002.

Steffen, W. et al. (2011) 'The anthropocene: Conceptual and historical perspectives', Philosophical Transactions of the Royal Society A: Mathematical, Physical and Engineering Sciences, 369(1938), pp. 842-867. doi: 10.1098/rsta.2010.0327.

Steffen, W., Crutzen, P. J. and McNeill, J. R. (2007) 'The Anthropocene: Are Humans Now Overwhelming the Great Forces of Nature', AMBIO: A Journal of the Human Environment, 36(8), pp. 614621. doi: 10.1579/00447447(2007)36[614:TAAHNO]2.0.CO;2

Thornbury W.D (1954) Principles of Geomorphology. New York: John Wiley \& Sons.

Vannote, R. L. et al. (1980) 'PERSPECTIVES The River Continuum Concept l',
Canadian Journal of Fisheries and Aquatic Sciences, 37(1)(1), pp. 130137. doi: https://doi.org/10.1139/f80017.

Verburg, P. H. et al. (2016) 'Methods and approaches to modelling the Anthropocene', Global Environmental Change. Elsevier Ltd, 39, pp. 328-340. doi:10.1016/j.gloenvcha.2015.08.007.

Waters, C. N. et al. (2016) 'The Anthropocene is functionally and stratigraphically distinct from the Holocene', Science, 351(6269).

doi: 10.1126/science.aad2622.

Widiyanto, K. et al. (2013) 'Dampak Aktivitas Penambangan Pasir di Sungai Lukulo Terhadap Airtanah Dangkal di Pesanggrahan Karangsambung, Kebumen, Jawa Tengah', Prosiding Pemaparan Hasil Penelitian Puslit Geoteknologi - LIPI2013, pp. 978-979.

Widiyanto, K. and Raharjo, P. D. (2011) 'Evaluasi aktivitas penambangan diabas di gunung parang cagar alam geologi karangsambung kebumen dengan pendekatan satuan genetika wilayah', rosiding Pemaparan Hasil Penelitian Puslit Geoteknologi LIPI, pp. 141-147.

Wohl, E. (2018) 'Rivers in the Anthropocene: The U.S. perspective', Geomorphology. Elsevier B.V., (xxxx). doi: 10.1016/j.geomorph.2018.12.001.

Yunus, H. S. (2010) Metodologi Penelitian Wilayah Kontemporer. Cetakan 1,. Yogyakarta: Pustaka Pelajar.

Zalasiewicz, J. et al. (2011) 'The anthropocene: A new epoch of geological time?', Philosophical Transactions of the Royal Society A: Mathematical, Physical and Engineering Sciences, 369(1938), pp. 835-841. doi: https://doi.org/10.1098/rsta.2010.0339.

Zalasiewicz, J. . et al. (2010) 'The new world of the anthropocene', Environmental Science and Technology, 44(7), pp. 2228-2231. doi: 10.1021/es903118j. 